\title{
Accounting
}

\section{Factors affecting capital structure of businesses in real estate sector on stock exchange}

\author{
Nguyen Ho Phi Ha ${ }^{a^{*}}$ and Mai Thanh Tu
}

${ }^{a}$ Academy of Finance, Hanoi, Vietnam. No. 58 Le Van Hien, Duc Thang ward, Bac Tu Liem district, Hanoi, Vietnam

${ }^{b}$ Center for Economics Development Studies, VNU University of Economics and Business, Vietnam

\section{H R O N I C L E}

Article history:

Received: January 1, 2021

Received in revised format:

April 32021

Accepted: April 4, 2021

Available online:

April 6, 2021

Keywords:

Real estate

Capital structure

Stock exchange

Renewable energy

\section{A B S T R A C T}

Based on the financial statements of real estate companies listed on Vietnamese stock market, the study has been conducted on factors affecting capital structure. The paper uses GLS (generalized least squared) estimation method related to panel data as well as testing to select the most appropriate model. Research results show that profitable real estate businesses, the ratio of fixed assets to total assets and the number of years of operation have a negative effect on capital structure. In contrast, renewable energy, size and growth are three factors that have positive effects on capital structure. In addition, the corporate income tax rate does not affect the capital structure decisions of real estate businesses. Through research, recommendations for the real estate business executives have been proposed to build an effective capital structure.

\section{Introduction}

Theoretically, the capital structure will significantly change depending on many factors, but often focus on the following characteristics: situation of each enterprise, the field in which the business operates as well as the effects from macro-volatility of the economy, cultural factors, religion, and governance behavior (Vanacker \& Manigart, 2010). Instead of finding out what the optimal ratio of debt to equity is, financial researchers are often interested in finding out the factors that influence the decision to use borrowed capital. In other words, using financial leverage of businesses (Sheikh \& Wang, 2011). It is from the correlation between these influencing factors with capital structure, we can evaluate whether the decision to use the enterprise's loan or equity is reasonable or not reasonable, there are shortcomings and what risks arise from which to propose solutions to improve the efficiency of using financial leverage and maximize asset value for businesses (Othman et al., 2020; Gharaibeh, 2015). In the case of Vietnam, Vietnam is planning to improve its infrastructure, and as a positive plus to foreign investors regarding the real estate sector, and energy sector. In the past, few foreign investors have been able to invest in real estate because of maintaining policy of unfavorable and strict foreign ownership. In addition, Vietnam is booming the middle class and quick urbanization pace and as the pillars for enhancing the real estate market. In agreement with the Ministry of Construction, the middle class increased a double rate to 30 million people, and will continue to increase to more than 50 million in 2030 . Furthermore, Vietnam has greatly attracted lots of foreign investment in the $21^{\text {st }}$ century, it means that foreign investors increasingly become a main player and shareholders in the Vietnam market. Additionally, over the past two decades, Vietnam has shown a dramatic increase in energy demand with a forecast change by 10 percent annually. To meet the booming demand,

\footnotetext{
* Corresponding author.

E-mail address: nguyenhphiha@hvtc.edu.vn (N. H. P. Ha) 
Vietnam has to construct a large number of energy factories with supplying approximately 60.000 MW of electricity by 2020, 96.500 MW by 2025, and 129.500 MW by 2030 (Nguyen, Abbott, \& Nguyen, 2019; Paramati, Sinha, \& Dogan, 2017).

Energy is an essential factor of social and economic life all over the world. Fossil fuels and coals are considered as major sources of energy which is limited and consumed by usage (Luong, 2015). The consumption of fossil fuels and coals may cause bad impacts on the environment such as land pollution, water pollution and global warming. It is expected that the global average temperature may increase, therefore, these problems affect the living standard of the nation's residents. So, it is necessary to overcome these problems for this purpose, renewable energy is a great solution. Vietnam has been an active member of the Paris climate change Conference since 2015. The purpose of this conference is to sustain temperature below $2{ }^{\circ} \mathrm{C}$ and concern the promotion of renewable energy particularly. Globally, energy is converting from fossil fuel and coal to renewable energy (Haq, Nawaz, Akram, \& Natarajan, 2020). The reason is not because of scarcity of fossil fuel and coal resources but due to the change of climate and pollution (Ho, Oshita, Looi, Leong, \& Chuah, 2019). Renewable energy is considered as energy which is not exhausted by use. Wind, solar, water, biomass and geothermal heat are the basic sources of renewable energy. It is stated that "Renewable energy plays a significant role in sustainable and inclusive capital structure" (Apergis \& Gangopadhyay, 2020). Moreover, it is considered that multiple goals like enhancement of energy access, friendly environment and pollution reduction can be achieved by adopting renewable energy.

This study is concerned with the real estate sector of Vietnam. It is related to land, natural resources and immovable property on it. Vietnam is a developing country having 97 million population ranked as the third most populous country in Southeast Asia. It observed that the demand for electricity has been increasing rapidly for the past five years. To fulfill this increasing amount of capacity the country will need $\$ 150$ billion in capital investment. As Vietnam has tremendous natural endowments. It may take a wise future power plan to adopt renewable energy through hydro and lower cost solar and wind power (Gugliotta et al., 2017). This power plan may provide the best chance for capital structure with lowest risk and positive impact on public budgets. It will boost up the economy of Vietnam. The natural resources have capacity to produce power four to five kilowatthours per square meter for solar and 3,000 kilometers of coastlines with consistent winds in the range of 5.5 to 7.3 meters per second. The annual capacity of renewable energy generation is 3.4 gigawatts which is intended for export to Europe and the U.S (Van Nguyen et al., 2016). The ratio of financing the business either through debt or equity is termed as Capital structure. To find out the effect of renewable energy as an independent variable on capital structure by taking as a dependent variable in Vietnam is the purpose of this paper. Being a developing country most of the debt comes from banks and they do not give too many long-term loans with the higher interest rate as well. That is the reason the short-term loan is a prominent part of the capital structure of Vietnam (Wang, Nguyen, Duong, \& Thai, 2018). Having abundant natural resources, the Government of Vietnam decided to convert their fossil fuel and coal power plan into a renewable energy plan. This study finds out the significant relationship between renewable energy and capital structure formation. This research work has great importance for economists, policy makers, entrepreneurs and the community of a nation due to the association of renewable energy and capital structure formation. This may impact on the living standards and environment.

In order to answer this argument, this study aims to find out the factors affecting the capital structure of real estate enterprises in Vietnam. The finding from the study is expected to show policymakers, politicians, and researchers what main factors can affect capital structure choice in the case of Vietnam. To conduct this research, we follow some steps. Section 2 indicates theoretical overview while research models are in Section 3. In addition, Section 4 indicates empirical results, and Section 5 shows Conclusions and recommendations.

\section{Theoretical Overview}

Theoretically, Al-Najjar and Hussainey (2011)in their studies regarding capital structure, and perfect capital markets and state that the market value of a business is calculated as the future value of its future income and underlying assets and is dependent on its capital structure. In addition, in the case when the capital market is perfect, Chien et al. (2021) and Al-Najjar \& Hussainey (2011) argue that a business risk and a same annual expected return must have the same total value regardless of capital structure in a firm. Additionally, the value of a business must depend on the present value of its activities, not on the way or source of capital mobilization. Further discussed on this argument, El Ghoul, Guedhami, Kwok, and Mishra (2011)'s point of view indicate that in a well-functioning market, it is impossible that the CFO does not need to worry about the debt policy or the capital structure of that business. In fact, debt policy and planning an optimal capital structure are still difficult problems and the CFO's top concern is attached to the ultimate goal of maximizing shareholder value while ensuring safety, minimizing risks and costs of debt (Hussain, Hassan, Rafiq, Abdullah, \& Quddus, 2020; Sadiq et al., 2020).

Another point of view regarding how to apply capital structure in a business, according to the trade-off theory proposed by Noulas and Genimakis (2011), the trade-off theory is divided by researchers into two forms, including: static trade-off theory and dynamic trade - off theory. Firstly, capital structure trade-off theory has explained the effects of corporate income tax, personal income tax, and costs related to using debt in the capital structure of businesses. In addition, the trade-off theory has also explained the differences in capital structure between industries and enterprises. In which, enterprises with safe tangible 
assets and high profitability have high target debt ratio (Jaisinghani \& Kanjilal, 2017). Therefore, a business with low profitability, mainly intangible assets, and low debt ratios could be merged (Bandyopadhyay \& Barua, 2016).

Factors affecting capital structure of businesses have been focused in some empirical studies worldwide with a great contribution according to Bonini and Boraschi (2012), and Gharaibeh (2015). As shown by Bonini and Boraschi (2012) on a study in the United State listed companies covering in the period from 1950 to 2003. Main results in this study indicate that rate of fixed assets, profitability rate, firm size are factors that are important to affect the capital structure choice of the United State market. In addition, inflation is like an external macro factor that affects capital structure of enterprises. Similarly, a research by Gharaibeh (2015) with sample data collected from companies listed on the Kuwaiti stock exchange in main industries in Kuwait covering in the period from 2009 to 2013 and applying pooled ordinary least square method, research has shown that industry characteristics such as age, firm size, growth opportunities, liquidity and profitability affect the capital structure, ratio of total debt in total assets, in which profit is inversely related and other factors are positive.

As suggested in Sikveland and Zhang (2020) on a study in Norwegian industry conducting over a firm level data, especially capital structure is shown by long and short run debt, total debt, and liquidity. The results show that firm performance is negatively impacted to short run and total debt while positively impacted with liquidity. In addition, listed businesses could depend less on long, and short run debt than unlisted businesses, and have a greater liquidity, which could decrease its bankruptcy risk and a lower firm performance. The firm performance has greater influence on the capital structure of the company. If the financial performance of the company is favorable then its capital structure is also favorable of the company and vice versa. Renewable energy has the ability to improve the production level of the industry all over the world and it could have a favorable impact on the capital structure and economic conditions of the firm. In addition, Le, Le, Nguyen, Schnitzer, and Braunegg (2016) clearly stated the concept of renewable energy produced by infinite resources such as solar, wind, rain, tide, wave and geothermal. The term infinite is defined into two meanings either (1) energy which cannot reduce after being consumption like solar, wind and water energy (2) energy is self-renewable within a short time this process revise continuously such as biomass energy getting from plant and organic sources (Zhao, Zuo, Fan, \& Zillante, 2011). The growing and fast introduction of renewable energy is important for safety of energy, positive change in climate and economically friendly (Khuong, McKenna, \& Fichtner, 2019; Nawaz et al., 2020). To produce renewable energy the space factor is very crucial. A large area of land is required for generation and storage of everlasting energy to fulfill the energy demand (Chang, Zeng, Wang, \& Wu, 2019).

Energy has a significant impact on the economy of the firm as well as the country because all the industry depends on the energy sources and without the energy sources companies and countries could not survive. In addition, energy improves the production of the organization that could improve the financial performance and conditions of the organization that could lead towards favorable capital structure of the company. The renewable energy among all of the resources of the energy have significant influence on the economic growth of the firm and country. Technologies of renewable energy are divided into two sectors firstly is mainstream energy technology in which hydro power, wind and solar energy secondly emerging energy technology in which marine energy, solar photovoltaic, geothermal energy, and artificial photosynthesis (Dogan \& Seker, 2016). Most of the countries strengthen power generation from renewable energy resources. For emerging countries like Vietnam, it is challenging for adopting renewable energy plans due to its higher cost than their financial capacity. The theory of capital structure presented by Y. Chang, Fang, and Li (2016) described that it does not concern in the perfect capital market how to finance. The market value of debt and equity collectively consider as total value that is constant irrespective of proportion of debt and equity. This capital structure is influenced by the renewable energy consumption of the country. If favorable consumption of renewable energy has taken place then the equity part of the capital structure increases while debt part of capital structure decreases due to growth in the economy and improvement of other economic factors in the country (Wei et al., 2020). However, if unfavorable consumption of renewable energy has been take place then the debt part of the capital structure increases while equity part of capital structure is decrease due to lack of growth in the economy and high investment on the environmental concerns and other economic factors in the country (Bauwens \& Defourny, 2017). In addition, a study by McPherson and Tahseen (2018) exposed that the investment on renewable energy and its consumption put favorable impact on the capital structure of the organization. The consumption motive of renewable energy could also influence the structure of the capital such as favorable consumption increase favorable capital structure and vice versa (Best, 2017). Moreover, the renewable energy investment and its favorable consumption lead the economies towards the growth that could have a favorable impact on the capital structure of the country (Lopes, 2016). Based on all the stated above literature, it is exposed that growth, effective use of renewable energy, size of the organization, tangibility and the age of the business have significant association with the capital structure of the country. Thus, the aim of the present study is to examine all of these factors' impact on the capital structure.

\section{Data and Methodology}

\subsection{Data}

The data used in this study are panel data collected from audited financial statements for 8 years from 2011 to 2018 of real estate companies on Ho Chi Minh Stock Exchange and Hanoi Stock Exchange and also extracted data from World Bank Indicators (WDI). 


\subsection{Methodology}

General model is of the form:

$$
\mathrm{Y}_{\mathrm{it}}=\alpha+\beta_{\mathrm{k}} \mathrm{X}_{\mathrm{kit}}+\mathrm{u}_{\mathrm{it}}
$$

where

$\mathrm{Y}_{\mathrm{it}}$ is the value of the dependent variable corresponding to enterprise $i$ at time $t$,

$\mathrm{X}_{\mathrm{kit}}$ are independent variable vectors collected based on previous studies to explain to $\mathrm{Y}_{\mathrm{it}}$,

$\mathrm{u}_{\mathrm{it}}$ is the random error of enterprise $i$ at time $t$.

Based on the general model, the author expanded to a simple multivariate regression model identified as follows:

$Y_{i t}=\alpha_{0}+\beta_{1} R_{0 A} A_{i t}+\beta_{2}$ ENERGY $_{i t}+\beta_{3}$ SIZE $_{i t}+\beta_{4}$ TANGIBLE $_{i t}+\beta_{5}$ GROWTH $_{i t}+\beta_{6} T A X_{i t}+\beta_{7}$ Year $_{i t}+e_{i t}$

In this research, we will analyze according to ordinary least square, fixed effects models and random effects models which only give robust and unbiased results with the assumption that the error of the population regression model has constant variance, that is, they have the same variance. In addition, the regression model also has no serial correlation between the errors, i.e. there is no autocorrelation phenomenon. If one of the two assumptions is violated, the regression coefficients of the estimated model are no longer the most effective estimation. In this case, the Generalized Least Squares (GLS) method should be applied to correct this violation (Chakraborty \& Mukherjee, 2020). The detailed description of the variables in the regression model could be analyzed according Table 1 as follows:

Table 1

Detailed description of variables in regression model

\begin{tabular}{|c|c|c|c|c|}
\hline Variable & Meaning & Definition & Expectation & Previous research \\
\hline \multicolumn{5}{|l|}{ Dependent variable } \\
\hline LEVERAGE & $\begin{array}{l}\text { Proxy of the capital structure of } \\
\text { the business }\end{array}$ & Ratio of debt in total assets & 1 & \\
\hline \multicolumn{5}{|c|}{ Independent variables } \\
\hline ROA & Profitability of the business & Ratio of profit after tax in total assets & - & Ab Wahab and Ramli (2013) \\
\hline $\begin{array}{l}\text { RENEWABLE } \\
\text { ENERGY }\end{array}$ & $\begin{array}{l}\text { The consumption of renewable } \\
\text { energy }\end{array}$ & $\begin{array}{l}\text { Renewable energy consumption }(\% \text { of } \\
\text { total energy consumption }\end{array}$ & + & Le et al. (2016) \\
\hline SIZE & The size of the business & $\begin{array}{l}\text { Logarithm of total assets of the } \\
\text { enterprise }\end{array}$ & + & Ab Wahab and Ramli (2013) \\
\hline TANGIBLE & Fixed assets of the business & The ratio of fixed assets in total assets & + & (Jõeveer, 2013) \\
\hline GROWTH & $\begin{array}{l}\text { Growth opportunities of the } \\
\text { business }\end{array}$ & $\begin{array}{l}\text { Difference of revenue of this year and } \\
\text { of previous year divided by revenue of } \\
\text { previous year }\end{array}$ & + & Gharaibeh (2015) \\
\hline TAX & Corporate income tax rate & $\begin{array}{l}\text { Ratio of corporate income tax in profit } \\
\text { before tax }\end{array}$ & - & (Jõeveer, 2013) \\
\hline YEAR & $\begin{array}{l}\text { The number of years of } \\
\text { operation of the business }\end{array}$ & $\begin{array}{l}\text { Natural logarithm of the period from } \\
\text { the year of establishment to } 2018\end{array}$ & + & (Jõeveer, 2013) \\
\hline
\end{tabular}

Source: the authors' synthesis

\section{Estimated Results}

The results show the descriptive statistics that exposed the minimum and maximum values along with standard deviation and mean values of the variables. Table 2 shows the 65 percent capital in a business is supported by debt while there exists a firm with high leverage. Further, firm performance measured by ROA, which is approximately 15.67 percent, and this value is quite good. Regarding firm growth, it indicates that this growth has significantly increased at approximately 22.345 percent.

Further discussed, this study is to measure the factors affecting capital structure of real estate companies listed on the stock market of Vietnam, particularly the cash dividend policy of real estate companies, we will conduct the method based on 3 models such as POLS (Pooled Ordinary Least Square), FEM (Fixed effects model), REM (Random effects model). Then, we will use the tests to choose the appropriate model and overcome the defects of the selected model as the results of the study. In order to overcome the heteroscedasticity of REM to make the estimation results be unbiased and effective, the authors use the feasible GLS estimate (FGLS). 
Table 2

Descriptive Statistics

\begin{tabular}{lcccc}
\hline Variable & Number of obs. & Mean & Standard deviation & Minimum \\
\hline LEVERAGE & 468 & 0.65675 & 0.5246 & 0.01123 \\
RENEWABLE ENERGY & 468 & 0.42135 & 0.3845 & 0.13951 \\
ROA & 468 & 0.1567 & 0.09123 & -0.4234 \\
SIZE & 468 & 4.2542 & 0.69432 & 3.9543 \\
TANGIBLE & 468 & 0.3678 & 0.6284 & 0.0002 \\
GROWTH & 468 & 0.22345 & 0.25675 & -1.08654 \\
TAX & 468 & 0.08733 & 3.4346 & -0.03123 \\
YEAR & 468 & 0.9567 & 0.1346 & 0.38432 \\
\hline
\end{tabular}

Source: results from Stata

The results also show the correlation matrix of the study and the figures highlighted that the renewable energy, size and growth have positive association with ROA while tangibility, tax and age have negative association with the ROA. These findings are shown in Table 3.

Table 3

Correlation matrix

\begin{tabular}{lrrrrrrr}
\hline \multicolumn{1}{c}{ Variables } & ROA & ENERGY & SIZE & GROW & TANG & TAX & AGE \\
\hline ROA & 1.000 & & & & & & \\
ENERGY & 0.251 & 1.000 & & & & \\
SIZE & 0.292 & -0.280 & 1.000 & & & \\
GROW & 0.166 & 0.174 & -0.548 & 1.000 & & \\
TANG & -0.408 & 0.032 & -0.165 & 0.259 & 1.000 & \\
TAX & -0.132 & -0.402 & 0.579 & -0.102 & 0.167 & 1.000 \\
AGE & -0.539 & -0.001 & -0.081 & 0.160 & 0.806 & 0.271 \\
\hline
\end{tabular}

The results also exposed the variance inflation factor (VIF) that shows the multicollinearity assumption of the model. The figures highlighted that the values of VIF are less than five that is the indication of no multicollinearity issue in the model. These values are highlighted in Table 4.

Table 4

Variance Inflation factor (VIF)

\begin{tabular}{lrr}
\hline & VIF & $1 /$ VIF \\
\hline ENERGY & 3.098 & .323 \\
SIZE & 3.021 & .331 \\
GROW & 2.516 & .397 \\
TANG & 2.202 & .454 \\
TAX & 1.659 & .603 \\
AGE & 1.235 & .81 \\
Mean VIF & 2.288 &. \\
\hline
\end{tabular}

The outcomes also show the Hausman test that is used to examine the appropriate model for the study. The probability value of the Hausman test is less than 0.05 that shows a fixed effect model (FEM) is appropriate because it rejects the null hypothesis about the random effect is appropriate for the study. These figures are shown in Table 5.

\section{Table 5}

Hausman test

\begin{tabular}{lc}
\hline & Coef. \\
\hline Chi-square test value & 31.165 \\
P-value & 0 \\
\hline
\end{tabular}

The outcomes show that the renewable energy along with growth and size have positive association with ROA while tax, age and tangibility have negative association with ROA of the study. According to the FEM, one percent increase in renewable energy could increase the ROA by 4.21 percent while one percent increase in size would increase the ROA by 84.67 percent. In addition, one percent increase in growth could increase the ROA by 3.45 percent however one percent increase in tangibility would decrease the ROA by 33.34 percent. Moreover, one percent increase in tax could decrease the ROA by 5.53 percent while one percent increase in age would decrease the ROA by 74.67 percent. These statistics are highlighted in Table 6. 


\section{Table 6}

Results of regression models

\begin{tabular}{|c|c|c|c|c|}
\hline & POLS & FEM & REM & FGLS \\
\hline ROA & $-1.7674 * * *$ & $-0.3234 * * *$ & $-0.54657 * * *$ & $-0.52323 * * *$ \\
\hline RENEWABLE ENERGY & $0.0395 * * *$ & $0.0421 * * *$ & $0.03284 * * *$ & $0.4935 * * *$ \\
\hline SIZE & $0.03435^{* *}$ & $0.8467 * * *$ & $0.4454 * * *$ & $0.63434 * * *$ \\
\hline TANG & $-0.3456 * * *$ & $-0.3343 *$ & $-0.7576^{* *}$ & $-0.7354 * * *$ \\
\hline GROW & $0.16876 * * *$ & $0.03456 * *$ & $0.2124^{*}$ & $0.04232 * * *$ \\
\hline TAX & $0.98342 * * *$ & $-0.0553^{*}$ & $0.04231 *$ & -0.0243 \\
\hline AGE & $-0.1356 * * *$ & $-0.7467 * *$ & $-0.1342 * *$ & $-0.17873 * *$ \\
\hline $\mathrm{N}$ & 468 & 468 & 468 & 468 \\
\hline $\mathrm{R} 2$ & 0.3232 & 0.3434 & 0.3544 & 0.3456 \\
\hline
\end{tabular}

Source: results from Stata software

\section{Discussions}

The regression results from the FGLS model in Table 6 show that the important factors such as ROA, TANGIBLE, YEAR, which have a negative influence on the capital structure of real estate enterprises. This finding is supported by a study of $A b$ Wahab and Ramli (2013), ROA has a negative impact on capital structure. In contrast, the results of TANGIBLE obtained in this study are not similar to these of (Jõeveer, 2013). This evidence can be explained that tangible assets in real estate enterprises do not support capital structure in the case of Vietnam while numerous empirical studies found an adverse impact in this relationship. Vietnam should enhance more efficiency regarding tangible assets. The results of FEM, REM and FGLS exposed that the ROA has significant but negative association with the capital structure of the country and this could be similar to the outcomes of the Ab Wahab and Ramli (2013) who also exposed that the ROA have negatively associated with the capital structure because it changed the capital structure according to the low and high profitability against assets. In addition, the results of FEM, REM and FGLS also exposed that the renewable energy has significant and positive association with the capital structure of the country and this could be matched with the outcomes of the Jõeveer (2013) who also examined that the renewable energy has significant effect on the capital structure because it improves the economy of the country by improving the production level of the industry and if country are economy strong then it has positive impact on the capital structure and vice versa. In addition, the results of FEM, REM and FGLS also exposed that the size has significant and positive association with the capital structure of the country. If the organizations, market and country are very big in size it also has greater influence on the economic condition and favorable economic condition could increase the capital structure and vice versa. These outcomes are also in line with the results of Jõeveer (2013) who also exposed that the size of the industry could improve the capital structure of the industry.

However, the results of FEM, REM and FGLS exposed that the tangibility has significant but negative association with the capital structure of the country. These outcomes are in line with the results of the Al-Najjar and Hussainey (2011) who also exposed that the tangibility of the market has negative linkage with the capital structure of the market. Furthermore, the results of FEM, REM and FGLS also exposed that the growth has significant and positive association with the capital structure of the country. The economic growth has played a significant impact on the capital structure because if the economic conditions of the country is favorable then effective capital structure exists in the country. These outcomes are matched with the findings of Dang, $\mathrm{Vu}, \mathrm{Ngo}$, and Hoang (2019) who also exposed that the economic conditions put a significant impact on the capital structure of the country. In addition, the results of FEM show the negative association among the tax and capital structure while REM and FGLS show the positive association among the capital structure and tax. These outcomes are in line with the findings of the McPherson and Tahseen (2018) who also exposed that if the tax system is favorable and companies are in position to pay high tax then it means they are economically strong and have favorable capital structure. Finally, the results of FEM, REM and FGLS exposed that the age has significant but negative association with the capital structure of the country. These outcomes are also similar to the output of the Gharaibeh (2015) who also exposed that the age of the companies put a negative impact on the capital structure of the country. Finally, this study found that factors such as SIZE, GROWTH, and RENEWABLE ENERGY which have a positive influence ratio of the debt in the total assets of the real estate business. A larger firm has a better capital structure in their operation activities. This finding is also found in the study of Gharaibeh (2015) with sample data collected from companies listed on the Kuwaiti stock exchange. In fact, a larger firm with less volatile profitability also has a greater likelihood of being able to use tax shields. Further, a firm with a good reputation can be able to access cheaper from financing cost, and therefore enhance firm value and an optimal capital structure. Taxes can affect the use of interest-paying debt. Increases in corporate tax rates can lead to increases in leverage, and increases in personal taxes on interest income. In this research, we found that the corporate income tax rate TAX is not statistically significant or in other words does not affect the capital structure of the real estate businesses. This finding is very different from that of (Jõeveer, 2013) who found a negative relationship between corporate income tax rate and capital structure. 


\section{Conclusion and recommendations}

Determining factors affecting the capital structure choice of the real estate businesses has greatly analyzed by numerous empirical studies worldwide, and it can support the overview how other factors affect the value of businesses, and its capital structure. Research results indicate that ROA, TANGIBLE, YEAR, which have a negative influence on the capital structure of real estate enterprises while SIZE, GROWTH, and RENEWABLE ENERGY which have a positive influence ratio of the debt in the total assets of the real estate business, but no impact for TAX. This study also recommends some solutions for the real estate businesses associated with the identification target capital structure. Specifically, the real estate businesses need to consider the characteristics that affect the debt-to-total assets ratio of real estate businesses in order to determine the target capital structure. This study finds out the significant relationship between renewable energy and capital structure formation. This research work has great importance for economists, policy makers, entrepreneurs and community of a nation due to the association of renewable energy and capital structure formation. This may impact on the living standards and environment. Therefore, businesses should have:

Firstly, real estate businesses should improve business efficiency. Research results show that business performance has a negative relationship with financial leverage. When operating effectively, companies in the real estate industry tend to use less debt, which will save businesses the cost of capital. Instead of using debt, real estate businesses can take advantage of internal capital from retained earnings because this type of capital costs lower than debt and issues new shares. Besides, when the efficiency is effective, enterprises will be more appreciated by creditors as well as more trusted by investors in the financial market.

Secondly, the empirical research results also show that the growth rate of real estate enterprises has a positive relationship with the ratio of debt to total assets of enterprises meanwhile the number of years of operation has an inverse relationship with enterprises. On that basis, financial managers need to develop development plans for real estate businesses to be specific, considering each stage of operation of the real estate industry in order to assess the growth ability of businesses each year, each stage to have a mechanism to mobilize appropriate funding sources.

Thirdly, taking advantage of the size of assets when using debt. Based on research results, it can be seen that there is a positive relationship between the size of real estate businesses and debt. With a greater business size, a firm will be easy to borrow from creditors compared to small and medium-sized real estate businesses. Therefore, using more debt, real estate companies should consider the advantage of firm size to be able to borrow with low cost of capital.

Fourthly, maximizing the benefits of using debt. Loans are also known as financial leverage since if the loan capital is exploited effectively, real estate businesses will improve the efficiency of using equity. In order to maximize the benefits of debt, businesses should flexibly use different forms of debt instead of depending heavily on commercial banks today. For the shortterm debts, real estate enterprises can negotiate to use commercial paper or dealing with the seller to use appropriate capital. For the long-term debts, food businesses can rent finance, issue bonds, convertible bonds on the stock market. The flexible diversification of mobilizing capital sources will help businesses realize fair balance between costs and capital as well as reaping the benefits of the tax shield.

This study has some limitations that could be the directions for future studies such as it takes only some factors of the economy such as size, tangibility, profitability, renewable energy, age and growth while many other economic factors exist and suggested that future studies should add other factors in their studies. In addition, the present study is on the economy of Vietnam and suggested that future studies should add the cross country analysis in their studies.

\section{References}

Ab Wahab, S. N. A., \& Ramli, N. A. (2013). Determinants of capital structure: An empirical investigation of Malaysian listed government linked companies (GLCs). Available at SSRN 2364238, 4(4), 930-945. doi: http://dx.doi.org/10.2139/ssrn.2364238

Al-Najjar, B., \& Hussainey, K. (2011). Revisiting the capital-structure puzzle: UK evidence. The Journal of Risk Finance, 12(4), 329-338. doi: https://doi.org/10.1108/15265941111158505

Apergis, N., \& Gangopadhyay, P. (2020). The asymmetric relationships between pollution, energy use and oil prices in Vietnam: Some behavioural implications for energy policy-making. Energy policy, 140, 1-12. doi: https://doi.org/10.1016/j.enpol.2020.111430

Bandyopadhyay, A., \& Barua, N. M. (2016). Factors determining capital structure and corporate performance in India: Studying the business cycle effects. The Quarterly Review of Economics and Finance, 61, 160-172. doi: https://doi.org/10.1016/j.qref.2016.01.004

Bauwens, T., \& Defourny, J. (2017). Social capital and mutual versus public benefit: The case of renewable energy cooperatives. Annals of Public and Cooperative Economics, 88(2), 203-232. doi: https://doi.org/10.1111/apce.12166

Best, R. (2017). Switching towards coal or renewable energy? The effects of financial capital on energy transitions. Energy 
Economics, 63, 75-83. doi: https://doi.org/10.1016/j.eneco.2017.01.019

Bonini, S., \& Boraschi, D. (2012). Corporate scandals and capital structure Entrepreneurship, Governance and Ethics (pp. 241269): Springer.

Chakraborty, S., \& Mukherjee, S. (2020). A Study on Customer's Satisfaction towards Brands of Select Fast Moving Consumer Goods. GIS Business, 15(2), 88-103. doi: https://ssrn.com/abstract=3546913

Chang, K., Zeng, Y., Wang, W., \& Wu, X. (2019). The effects of credit policy and financial constraints on tangible and research $\&$ development investment: Firm-level evidence from China's renewable energy industry. Energy policy, 130, 438-447. doi: https://doi.org/10.1016/j.enpol.2019.04.005

Chang, Y., Fang, Z., \& Li, Y. (2016). Renewable energy policies in promoting financing and investment among the East Asia Summit countries: Quantitative assessment and policy implications. Energy policy, 95, 427-436. doi: https://doi.org/10.1016/j.enpol.2016.02.017

Chien, F., Sadiq, M., Kamran, H.W. et al. Co-movement of energy prices and stock market return: environmental wavelet nexus of COVID-19 pandemic from the USA, Europe, and China. Environ Sci Pollut Res (2021). https://doi.org/10.1007/s11356021-12938-2

Dang, H. N., Vu, V. T. T., Ngo, X. T., \& Hoang, H. T. V. (2019). Study the impact of growth, firm size, capital structure, and profitability on enterprise value: Evidence of enterprises in Vietnam. Journal of Corporate Accounting \& Finance, 30(1), 144-160. doi: https://doi.org/10.1002/jcaf.22371

Dogan, E., \& Seker, F. (2016). The influence of real output, renewable and non-renewable energy, trade and financial development on carbon emissions in the top renewable energy countries. Renewable and Sustainable Energy Reviews, 60, 1074-1085. doi: https://doi.org/10.1016/j.rser.2016.02.006

El Ghoul, S., Guedhami, O., Kwok, C. C., \& Mishra, D. R. (2011). Does corporate social responsibility affect the cost of capital? Journal of Banking \& Finance, 35(9), 2388-2406. doi: https://doi.org/10.1016/j.jbankfin.2011.02.007

Gharaibeh, A. M. O. (2015). The determinants of capital structure: Empirical evidence from Kuwait. European Journal of Business, Economics and Accountancy, 3(6), 1-25.

Gugliotta, M., Saito, Y., Nguyen, V. L., Ta, T. K. O., Nakashima, R., Tamura, T., . . Yamamoto, S. (2017). Process regime, salinity, morphological, and sedimentary trends along the fluvial to marine transition zone of the mixed-energy Mekong River delta, Vietnam. Continental Shelf Research, 147, 7-26. doi: https://doi.org/10.1016/j.csr.2017.03.001

Haq, M. A. U., Nawaz, M. A., Akram, F., \& Natarajan, V. K. (2020). Theoretical Implications of Renewable Energy using Improved Cooking Stoves for Rural Households. International Journal of Energy Economics and Policy, $10(5), 546-554$.

Ho, S. S., Oshita, T., Looi, J., Leong, A. D., \& Chuah, A. S. (2019). Exploring public perceptions of benefits and risks, trust, and acceptance of nuclear energy in Thailand and Vietnam: A qualitative approach. Energy policy, 127, 259-268. doi: https://doi.org/10.1016/j.enpol.2018.12.011

Hussain, S., Hassan, A. A. B. G., Rafiq, M., Abdullah, M., \& Quddus, A. (2020). Impact of investment decisions and interest rate on firm's financial performance of Fuel and Energy Sector of Pakistan. International Journal of Advanced Science and Technology, 29(4), 1391-1410.

Jaisinghani, D., \& Kanjilal, K. (2017). Non-linear dynamics of size, capital structure and profitability: Empirical evidence from Indian manufacturing sector. Asia Pacific Management Review, 22(3), 159-165. doi: https://doi.org/10.1016/j.apmrv.2016.12.003

Jõeveer, K. (2013). Firm, country and macroeconomic determinants of capital structure: Evidence from transition economies. Journal of Comparative Economics, 41(1), 294-308. doi: https://doi.org/10.1016/j.jce.2012.05.001

Khuong, P. M., McKenna, R., \& Fichtner, W. (2019). Analyzing drivers of renewable energy development in Southeast Asia countries with correlation and decomposition methods. Journal of cleaner production, 213, 710-722. doi: https://doi.org/10.1016/j.jclepro.2018.12.192

Le, T. H., Le, Q. V., Nguyen, T. P. T., Schnitzer, H., \& Braunegg, G. (2016). An integrated ecosystem incorporating renewable energy leading to pollution reduction for sustainable development of craft villages in rural area: a case study at sedge mats village in Mekong Delta, Vietnam. Energy, Sustainability and Society, 6(1), 21-25. doi: https://doi.org/10.1186/s13705-0160088-6

Lopes, B. M. D. G. (2016). Capital structure and risk mitigation in the renewable energy sector: the public-private partnership experience in Cabo Verde. Instituto Superior de Economia e Gestão.

Luong, N. D. (2015). A critical review on potential and current status of wind energy in Vietnam. Renewable and Sustainable Energy Reviews, 43, 440-448. doi: https://doi.org/10.1016/j.rser.2014.11.060

McPherson, M., \& Tahseen, S. (2018). Deploying storage assets to facilitate variable renewable energy integration: The impacts of grid flexibility, renewable penetration, and market structure. Energy, 145, 856-870. doi: https://doi.org/10.1016/j.energy.2018.01.002

Nawaz, M. A., Hussain, M. S., Kamran, H. W., Ehsanullah, S., Maheen, R., \& Shair, F. (2020). Trilemma association of energy consumption, carbon emission, and economic growth of BRICS and OECD regions: quantile regression estimation. Environmental Science and Pollution Research, 1-15.

Nguyen, P. A., Abbott, M., \& Nguyen, T. L. T. (2019). The development and cost of renewable energy resources in Vietnam. 
Utilities Policy, 57, 59-66. doi: https://doi.org/10.1016/j.jup.2019.01.009

Noulas, A., \& Genimakis, G. (2011). The determinants of capital structure choice: evidence from Greek listed companies. Applied Financial Economics, 21(6), 379-387. doi: https://doi.org/10.1080/09603107.2010.532108

Othman, Z., Nordin, M. F. F., \& Sadiq, M. (2020). GST fraud prevention to ensure business sustainability: A Malaysian case study. Journal of Asian Business and Economic Studies, 27(3), 245-265.

Paramati, S. R., Sinha, A., \& Dogan, E. (2017). The significance of renewable energy use for economic output and environmental protection: evidence from the Next 11 developing economies. Environmental Science and Pollution Research, 24(15), 13546-13560. doi: https://doi.org/10.1007/s11356-017-8985-6

Sadiq, M., Singh, J., Raza, M., \& Mohamad, S. (2020). The Impact of Environmental, Social and Governance Index on Firm Value: Evidence from Malaysia. International Journal of Energy Economics and Policy, 10(5), 555-562.

Sheikh, N. A., \& Wang, Z. (2011). Determinants of capital structure. Managerial finance, 37(2), 117-133. doi: https://doi.org/10.1108/03074351111103668

Sikveland, M., \& Zhang, D. (2020). Determinants of capital structure in the Norwegian salmon aquaculture industry. Marine Policy, 119(9), 104-116. doi: https://doi.org/10.1016/j.marpol.2020.104061

Van Nguyen, H., Nguyen, C. D., Van Tran, T., Hau, H. D., Nguyen, N. T., \& Gummert, M. (2016). Energy efficiency, greenhouse gas emissions, and cost of rice straw collection in the Mekong River Delta of Vietnam. Field crops research, 198, 16-22. doi: https://doi.org/10.1016/j.fcr.2016.08.024

Vanacker, T. R., \& Manigart, S. (2010). Pecking order and debt capacity considerations for high-growth companies seeking financing. Small Business Economics, 35(1), 53-69. doi: https://doi.org/10.1007/s11187-008-9150-x

Wang, C.-N., Nguyen, V. T., Duong, D. H., \& Thai, H. T. N. (2018). A hybrid fuzzy analysis network process (FANP) and the technique for order of preference by similarity to ideal solution (TOPSIS) approaches for solid waste to energy plant location selection in Vietnam. Applied Sciences, 8(7), 1100-1115. doi: https://doi.org/10.3390/app8071100

Wei, X., Che, H., Sheng, N., Hsiao, C., Tong, Q., \& Yan, G. (2020). Research on the Development Status of China's Renewable Energy Industry-The Impact of Capital Structure on Company Performance. Front. Energy Res, 8, 71-79. doi: doi: $10.3389 /$ fenrg.2020.00071

Zhao, Z.-Y., Zuo, J., Fan, L.-L., \& Zillante, G. (2011). Impacts of renewable energy regulations on the structure of power generation in China-a critical analysis. Renewable Energy, 36(1), 24-30. doi: https://doi.org/10.1016/j.renene.2010.05.015 

under the terms and conditions of the Creative Commons Attribution (CC-BY) license (http://creativecommons.org/licenses/by/4.0/). 